\title{
SELF-EFFICACY DAN DUKUNGAN KELUARGA DALAM KEBERHASILAN BELAJAR DARI RUMAH DI MASA PANDEMI COVID-19
}

\author{
Tita Tanjung Sari ${ }^{1)}$ \\ 1) Universitas Wiraraja \\ titatanjungfkip@wiraraja.ac.id
}

\begin{abstract}
ABSTRAK: Penelitian ini membahas tentang pengaruh self-efficacy dan dukungan keluarga terhadap keberhasilan belajar dari rumah di masa pandemi covid-19. Seperti yang kita ketahui bersama bahwa peserta didik mulai dari tingkat Sekolah Dasar hingga Perguruan tinggi di instruksikan untuk belajar dari rumah selama masa pendemi covid-19 ini. Penelitian ini menjadi sangat menarik mengingat waktu bejajar di rumah masih akan diperpanjang hingga waktu yang masih belum dapat diprediksi. Variabel yang dianalisis pada penelitian ini adalah Self-Efficacy, dukungan keluarga, dan keberhasilan belajar dari rumah selama proses pandemi covid-19. Penelitian ini bertujuan untuk mengetahui seberapa besar pengaruh Self-Efficacy, dan dukungan keluarga terhadap tingkat keberhasilan belajar dari rumah selama masa pandemi Covid-19. Penelitian ini menggunakan pendekatan deskriptif kuantitatif dengan Teknik pengambilan sampel secara proporsional random sampling. Penelitian ini melibatkan 50 responden dari 9 Kecamatan di Kabupaten Sumenep Provinsi Jawa Timur. Hasil pengujian hipotesis menunjukkan bahwa ada pengaruh dari Self-Efficacy dan dukungan keluarga terhadap tingkat keberhasilan belajar dari rumah salama masa pandemi Covid-19. Variabel independen X1 (Self-Efficacy) dan variabel X2 (dukungan keluarga) memberikan pengaruh sebasar 60,7\% terhadap suksesnya kegiatan belajar dari rumah dan selebihnya yaitu 39,3\% dipengaruhi oleh faktor lain yang tidak dijelaskan dalam model regresi yang diperoleh misalnya, kondisi geografis tempat tinggal siswa, stabilitas signal, dan kesiapan guru dalam proses pembelajaran daring di rumah
\end{abstract}

Kata kunci : Self-Efficacy, Dukungan Keluarga, Belajar Dari Rumah

ABSTRACT: This study discusses about the effect of self-efficacy and family support to the learning achievement at home during Covid-19 pandemic. As we know, the government officially announced that all major public schools, starting from the primary schools to higher level education have been instructed to practice distance learning during the pandemic. The practice of distance learning which has been extended to an uncertain period of time, leads to an interesting topic of this study. Variables of this study are self-efficacy, family support, and the learning achievement at home during covid-19 pandemic. The study intends to find out the significance of self-efficacy and family support to the learning achievement at home during covid19 pandemic. The approach of this study uses descriptive quantitative with proportional random sampling data collection technique, involving 50 respondents from 9 different sub-districts in Sumenep, East Java province. The result of hypothesis testing indicates that there is an effect of self-efficacy and family support to the learning achievement at home during covid-19 pandemic. The independent variable X1 (self-efficacy) and variable X2 (family support), the variation of dependent variable Y result (learning achiement at home during covid-19 pandemic) is $60.7 \%$, and the rest of $39.3 \%$ is affected by other unexplained factors in regression model such as geographical condition, the living environment, network stability, and the teacher preparation in the process of distance learning from home.

Keywords: Self-Efficacy, Family Support, Learning From Home.

\section{PENDAHULUAN}

Pandemi Covid-19 melanda seluruh belahan di dunia tak terkecuali Indonesia. Covid-19 berpengaruh pada seluruh aktivitas di republik ini bahkan seluruh penduduk 
dunia. Semua sektor menerima dampak dari pandemi ini, tak terkecuali pada Pendidikan di Indonesia. Semenjak merebaknya virus ini, mulai pertengahan Maret 2020 Presiden RI telah mengintruktuksikan kepada seluruh masyarakat Indonesia untuk bekerja, belajar, dan beribadah di rumah. Hal ini menjadi tantangan baru bagi dunia pendidikan Indonesia. Berdadasarkan instruksi tersebut, secara otomatis terjadi perubahan pada proses belajar seluruh siswa sekolah termasuk siswa tingkat Sekolah Dasar.

Pada jenjang Pendidikan tingkat Sekolah Dasar, belajar di rumah menjadi tantangan tersendiri bagi siswa dan orang tua walinya. Tidak semua orang tua siap menjadi guru "dadakan" bagi anaknya. Terlebih jika dalam sebuah keluarga memiliki lebih dari satu siswa tingkat sekolah dasar. Ini menjadi hal yang sangat menantang bagi orang tua. Saat belajar di rumah, tingkat keinginan anak untuk terus belajar, sikap mandiri peserta didik dan dukungan keluarga sangat berpengaruh pada keberhasilan balajar di rumah.

Bandura (Taylor, S.E. Peplau, L.T. Sears, D.O, 2009) mengemukakan bahwa peran efikasi diri sebagai mekanisme yang mendasari perubahan perilaku, pemeliharaan dan generalisasi. Park dan Kim (2006:276) menjelaskan efikasi diri akademik sangat penting bagi pelajar untuk mengontrol motivasi mencapai harapan-harapan akademik. Semakin tinggi Self-Efficacy seorang peserta didik, maka akan semakin tinggi pula rasa keyakinan dan kepercayaan diri peserta didik tersebut. Sehingga semakin tinggi rasa kepercayaan seseorang terhadap kemampuan diri sendiri, semakin kuat pula semangat untuk menyelesaikan pekerjaannya (Hendriana, 2014).

Self-Efficacy atau lebih familiar dengan efikasi diri adalah kemampuan diri untuk dapat menciptakan motivasi diri, rasa percaya diri, keyakinan pada diri sendiri, dan mampu mawas diri. Self-Efficacy dapat menciptakan pola kemandirian belajar bagi siswa. Bandura (dalam Ridhoni, 2013 : 230) seorang yang memiliki Self-Efficacy tinggi akan dapat membangun kemampuan lebih banyak melalui usaha secara terus menerus, sedangkan seseorang yang memiliki Self-Efficacy rendah akan menghambat perkembangan kemampuan yang dibutuhkan seseorang. Bandura juga mengatakan bahwa segala sesuatu sangat sulit dibandingkan keadaan yang sesungguhnya, sedangkan orang yang memiliki Self-Efficacy kuat akan mengembangakan perhatian dan usahanya terhadap tuntutan situasi dan di pacu oleh rintangan sehingga seseorang akan berusaha lebih keras. Self-Efficacy pada penelitian ini mencakup motivasi intrinsik siswa, keyakinan diri siswa, rasa percaya diri siswa, dan kemawasan diri siswa selama belajar di rumah di masa pendemi nasional. Self-Efficacy akan melahirkan pola kemandirian belajar bagi peserta didik selama belajar di rumah di masa pandemi nasional ini.

Pola kemandirian belajar ini lah yang menjadi tonggak terlaksananya proses belajar dari rumah. Selain Self-Efficacy yang dapat menciptakan pola kemandirian dan motivasi intrinstik siswa, dukungan orang tua juga menjadi hal krusial dalam pelaksanaan belajar dari rumah selama masa pandemi covid-19. Selama masa belajar dari rumah, orang tua menjadi guru sekaligus pengawas bagi putra putrinya. Rumah menjadi sekolah 
bagi putra putrinya. Dukungan keluarga yang diharapkan selama kegiatan belajar dari rumah tidak hanya sebatas pemberian fasilitas belajar selama di rumah saja, tetapi juga mencakup instrumental support dan emosional support.

Instrumental support meliputi bimbingan dari orang tua. Saat masa belajalar di rumah, orang tua dan keluarga menjadi objek awal tempat peserta didik bertanya dan meminta pertimbangan terkiat materi dan tugas belajarnya. Fungsi keluarga sebagai instrumental support yang lain adalah sebagai tempat mengadu dan berkeluh kesah pertama yang dapat diandalkan. Selain sebagai instrumental support, dukungan keluarga juga berperan sebagai emosional support. Dimasa perkembangan anak terutama usia sekolah dasar, keluarga diharapkan dapat menjadi satu-satunya tempat mencurahkan segala ekspresi cinta antara anak dan orang tua serta pemberian pengakuan kepada peserta didik. Saat ini lah menjadi saat terbaik baik keluarga untuk saling mendekatkan diri satu sama lain, saling mengungkapkan ekspresi rasa cinta dan kasih sayang satu sama lain, dan saling memupuk rasa percaya diri peserta didik. Penelitian ini bertujuan untuk mengetahui seberapa besar pengaruh dari Self-Efficacy dan dukungan keluarga selama belajar di rumah pada masa pandemic covid-19.

\section{METODE PENELITIAN}

Penelitian ini menggunakan pendekatan kuanitatif dengan jenis penelitian deskriptif kuantitatif. Cara pengambilan data pada Penelitian menggunakan Teknik survei. Teknik survei ini dilakukan untuk melihat fenomena yang terjadi di tempat penelitian. Penelitian ini dilakukan di kabupaten Sumenep dengan pengambilan sampel secara porposif proporsional random sampling. Subjek penelitian adalah siswa SD mulai kelas 1 hingga kelas 6 yang melakukan kegiatan belajar dari rumah selama masa pendemi covid-19. Dalam proses menentukan jumlah sampel di setiap tingkatan kelas peneliti menggunakan Teknik proporsional random. Jumlah keseluruhan sampel yang digunakan dalam penelitian ini adalah sebanyak 50 peserta didik di 9 kecamatan di Kabupaten Sumenep, diantaranya Kecamatan Kota, Kecamatan Batu Putih, Kecamatan Arjasa, Kecamatan Batuan, Kecamatan Kalianget, Kecamatan Kangayan, kecamatan Arjasa, kecamatan Sapeken, dan Kecamatan Batang-batang.

Angket survei yang digunakan pada penelitian ini meliputi instrument untuk mengukur Self-Efficacy, dukungan keluarga, dan keberhasilan proses belajar dari rumah selama masa pendemi covid-19. Selain itu juga peneliti menyiapkan lembar observasi dan wawancara dengan peserta didik dan keluarga agar dapat mendiskripsikan Self-Efficacy, dukungan orang tua, dan keberhasilan proses belajar dari rumah selama masa pandemic covid-19.

Penyebaran angket survey dilakukan melalui berbagai media, dan melibatkan tenaga survei dan observer dari mahasiswa yang merada di daerah masing-masing yang memiliki adik, atau saudara yang masih sekolah tingkat SD untuk di sebar kepada 
responden. Hasilnya akan di kirim kembali secara virtual untuk di analisis. Analisis data yang di gunakan adalah uji prasyarat yang terdiri dari uji normalitas dan uji linieritas, selanjutnya peneliti akan melakukan uji hipotesis.

\section{HASIL DAN PEMBAHASAN}

\section{a. Analisis Regresi Linier Berganda}

Perhitungan hasil analisis regresi linier berganda dalam penelitian ini dibantu dengan menggunakan program SPSS for windows's versi 20,00 untuk mendapatkan hasil yang lebih akurat. Analisis regresi linier berganda digunakan untuk mengetahui pengaruh variabel $\mathrm{X}_{1}$ (Self-Efficacy) dan variabel $\mathrm{X}_{2}$ (dukungan keluarga) terhadap variabel Y (hasil belajar dirumah saat pandemi Covid-19).

Hasil analisis Regresi Linier Berganda disajikan dalam tabel berikut :

\section{Coefficients $^{\mathrm{a}}$}

\begin{tabular}{|c|c|c|c|c|c|c|c|c|c|c|c|c|}
\hline \multirow[b]{2}{*}{ Model } & \multicolumn{2}{|c|}{$\begin{array}{l}\text { Unstandardiz } \\
\text { ed } \\
\text { Coefficients }\end{array}$} & \multirow{2}{*}{\begin{tabular}{|c|}
$\begin{array}{c}\text { Standardi } \\
\text { zed } \\
\text { Coefficien } \\
\text { ts }\end{array}$ \\
\\
Beta
\end{tabular}} & \multirow[b]{2}{*}{$\mathrm{t}$} & \multirow[b]{2}{*}{ Sig. } & \multicolumn{2}{|c|}{$\begin{array}{c}95 \% \\
\text { Confidence } \\
\text { Interval for B }\end{array}$} & \multicolumn{3}{|c|}{ Correlations } & \multicolumn{2}{|c|}{$\begin{array}{c}\text { Collinearity } \\
\text { Statistics }\end{array}$} \\
\hline & B & $\begin{array}{c}\text { Std. } \\
\text { Error }\end{array}$ & & & & $\begin{array}{l}\text { Lower } \\
\text { Bound }\end{array}$ & $\begin{array}{l}\text { Upper } \\
\text { Bound }\end{array}$ & $\begin{array}{l}\text { Zero- } \\
\text { order }\end{array}$ & Partial & Part & Tolerance & VIF \\
\hline 1 (Constant) & 1.805 & .840 & & 2.150 & .036 & .120 & 3.489 & & & & & \\
\hline $\mathrm{X} 1$ & .542 & .167 & .512 & 3.248 & .002 & .207 & .877 & .812 & .411 & .301 & .700 & 1.429 \\
\hline $\mathrm{X} 2$ & .271 & .128 & .650 & 2.121 & .039 & .015 & .528 & .308 & .282 & .197 & .962 & 1.039 \\
\hline
\end{tabular}

a. Dependent Variable: $\mathrm{Y}$

\begin{tabular}{|c|c|c|c|c|}
\hline Variabel dependent & $\begin{array}{c}\text { Variabel } \\
\text { independent }\end{array}$ & $\begin{array}{c}\text { Koefisien } \\
\text { regresi }\end{array}$ & $\mathbf{t}$ & signifikansi \\
\hline \multirow{3}{*}{$\begin{array}{c}\mathbf{Y} \\
\text { Hasil belajar dirumah selama } \\
\text { pandemi Covid-19 }\end{array}$} & Konstanta & 1.805 & 2,150 & 0,036 \\
\hline & $\mathrm{X}_{1}$ & 0,542 & 3,248 & 0,002 \\
\hline & $\mathrm{X}_{2}$ & 0,271 & 2,121 & 0,039 \\
\hline
\end{tabular}

Berdasarkan tabel diatas maka persamaan garis regresi linier berganda yang diperoleh dalam penelitian ini adalah sebagai berikut:

$$
Y=a+b_{1} X_{1}+b_{2} X_{2}+e_{i}=1,805+0,542 X_{1}+0,271 X_{2}+e_{i}
$$

Berdasarkan persamaan garis regresi linier berganda tersebut dapat dijelaskan bentuk pengaruh variabel $\mathrm{X}_{1}$ (Self-Efficacy) dan variabel $\mathrm{X}_{2}$ (dukungan keluarga) terhadap variabel Y (hasil belajar dirumah saat pandemi Covid-19) sebagai berikut: 
1) Besarnya nilai konstanta a menunjukkan nilai positif yaitu 1,805 , menunjukkan apabila variabel $\mathrm{X}_{1}$ (Self-Efficacy) dan variabel $\mathrm{X}_{2}$ (dukungan keluarga) serta $\mathrm{e}_{\mathrm{i}}$ dalam kondisi konstan atau nol (0), maka hasil belajar dirumah saat pandemi Covid-19 sebesar 1,805 atau apabila Self-Efficacy dan dukungan keluarga sudah diterapkan maka hasil belajar dirumah saat pandemi Covid-19 naik sebesar 1,805.

2) Koefisien regresi variabel $X_{1}$ (Self-Efficacy) adalah sebesar 0,542. Hal ini berarti variabel $\mathrm{X}_{1}$ (Self-Efficacy) memiliki pengaruh yang positif terhadap variabel $\mathrm{Y}$ (hasil belajar dirumah saat pandemi Covid-19). Apabila variabel $\mathrm{X}_{1}$ (SelfEfficacy) mengalami penambahan satu satuan dengan asumsi variabel lainnya konstan atau nol (0), maka akan menyebabkan bertambahnya variabel Y (hasil belajar dirumah saat pandemi Covid-19) sebesar 0,542.

3) Koefisien regresi variabel $X_{2}$ (dukungan keluarga) adalah sebesar 0,721. Hal ini berarti variabel $\mathrm{X}_{2}$ (dukungan keluarga) memiliki pengaruh yang positif terhadap variabel Y (hasil belajar dirumah saat pandemi Covid-19). Apabila variabel $\mathrm{X}_{2}$ (dukungan keluarga) mengalami penambahan satu satuan dengan asumsi variabel lainnya konstan atau nol (0), maka akan menyebabkan bertambahnya variabel Y (hasil belajar dirumah saat pandemi Covid-19) sebesar 0,721.

\section{b. Analisis Koefisien Determinasi Berganda $\left(\mathbf{R}^{\mathbf{2}}\right)$}

Koefisien determinasi berganda digunakan untuk mengukur besarnya pengaruh variabel bebas (X) terhadap variabel terikat (Y). Semakin besar nilai $\mathrm{R}^{2}$ (R Square), maka semakin kuat kemampuan model regresi yang diperoleh untuk menerangkan kondisi yang sebenarnya. Dari hasil analsis SPSS, disajikan sebagai berikut:

Model Summaryb

\begin{tabular}{|c|c|c|c|c|c|c|c|c|c|c|}
\hline \multirow[b]{2}{*}{ Model } & \multirow[b]{2}{*}{$\mathrm{R}$} & \multirow[b]{2}{*}{$\begin{array}{c}\mathrm{R} \\
\text { Square }\end{array}$} & \multirow[b]{2}{*}{$\begin{array}{l}\text { Adjusted } \\
\text { R Square }\end{array}$} & \multirow{2}{*}{$\begin{array}{c}\text { Std. Error } \\
\text { of the } \\
\text { Estimate }\end{array}$} & \multicolumn{5}{|c|}{ Change Statistics } & \multirow[b]{2}{*}{$\begin{array}{l}\text { Durbin- } \\
\text { Watson }\end{array}$} \\
\hline & & & & & $\begin{array}{c}\text { R Square } \\
\text { Change }\end{array}$ & $\begin{array}{c}\mathrm{F} \\
\text { Change }\end{array}$ & df1 & $\mathrm{df} 2$ & $\begin{array}{c}\text { Sig. F } \\
\text { Change }\end{array}$ & \\
\hline 1 & $.779^{\mathrm{a}}$ & .607 & .519 & .46028 & .553 & 16.108 & 2 & 47 & .000 & 1.919 \\
\hline
\end{tabular}

Berdasarkan analisis yang dilakukan, harga $\mathrm{R}$ Square harga koefisien $\mathrm{R}^{2}$ hitung (koefisien determinasi) yakni sebesar 0,607. Besaran ini menunjukkan pada efektifitas garis regresi yang diperoleh dalam menjelaskan variasi variabel dependen. Hasil tersebut dapat disimpulkan bahwa kemampuan variabel independen $\mathrm{X}_{1}$ (Self-Efficacy) dan variabel $\mathrm{X}_{2}$ (dukungan keluarga) untuk menjelaskan variasi pada variabel dependen $\mathrm{Y}$ (hasil belajar dirumah saat pandemi Covid-19) adalah sebesar 60,7\% selebihnya yaitu $39,3 \%$ dijelaskan oleh faktor lain yang tidak dijelaskan dalam model regresi yang diperoleh misalnya kondisi geografis tempat tinggal siswa, stabilitas signal dan kesiapan guru dalam proses pembelajaran daring di rumah. Tidak semua siswa dapat menikmati 
signal stabil seperti di kota besar. Dsiparitas infrasruktur juga sangat memengaruhi kualitas signal dan fasilitas proses belajar dari rumah. Beberapa responden manyatakan bahawa penjelasan guru saat proses belajar di rumah tidak sedetail bila dibandingkan saat guru menerangkan secara langsung. Banyak juga yang mengeluhkan dapatnya pelajaran siswa dan membandingan dengan pelajaran anak sekolah dasar dengan kurikulum sebelumnya.

\section{c. Uji T}

Uji T di gunakan untuk melihat signifikansi pengaruh dari variabel bebas X1 dan $\mathrm{X} 2$ secara parsial (individu) terhadap varibel terikat (Y) dengan level of signifikansi $\alpha=$ $5 \%$. Kriteria pengambilan keputussannya adalah :

1) Apabila $T_{\text {hitung }} \geq \mathrm{T}_{\text {taabel }}$ berarti $\mathrm{H}_{\mathrm{o}}$ ditolak dan $\mathrm{H}_{\mathrm{a}}$ diterima, jadi semua varibel bebas (Self-Efficacy dan dukungan keluarga) secara parsial memiliki pengaruh yang nyata terhadap varibael terikat (hasil belajar dirumah selama pandemi Covid-19)

2) Apabila $T_{\text {hitung }} \leq T_{\text {taabel }}$ berarti $H_{o}$ diterima dan $H_{a}$ ditolak, jadi semua varibel bebas (Self-Efficacy dan dukungan keluarga) secara parsial tidak memiliki pengaruh yang nyata terhadap varibael terikat (hasil belajar dirumah selama pandemi Covid-19)

Hasil analisis Uji T disajikan dalam tabel berikut :

\begin{tabular}{|l|c|c|c|l|}
\hline \multicolumn{1}{|c|}{ Variabel } & $\mathbf{T}_{\text {hitung }}$ & $\mathbf{T}_{\text {tabel }}$ & Sig & \multicolumn{1}{c|}{ keterangan } \\
\hline Self-Efficacy $\left(\mathrm{X}_{1}\right)$ & 3,248 & 2,012 & 0,002 & $\mathrm{H}_{\mathrm{o}}$ ditolak dan $\mathrm{H}_{\mathrm{a}}$ diterima \\
\hline Dukungan keluarga $\left(\mathrm{X}_{2}\right)$ & 2,121 & 2,012 & 0,039 & $\mathrm{H}_{\mathrm{o}}$ ditolak dan $\mathrm{H}_{\mathrm{a}}$ diterima \\
\hline
\end{tabular}

Berdasarkan hasil analisis uji t diatas, dapat disimpulkan sebagai berikut:

1) Pada variabel $X_{1}$ (Self-Efficacy) nilai $T_{\text {hitung }} \geq T_{\text {taabel }}(3,248 \geq 2,012)$ berarti $H_{o}$ ditolak dan $\mathrm{H}_{\mathrm{a}}$ diterima artinya variabel $\mathrm{X}_{1}$ (Self-Efficacy) memiliki pengaruh nyata dan signifikan secara parsial terhadap variabel $\mathrm{Y}$ (hasil belajar dirumah saat pandemi Covid-19 Self-Efficacy akan melahirkan motivasi intrinsic pada diri pesera didik untuk tetap disiplin di rumah. Mereka akan mempersiapkan kelengkapan belajar merek asecara mandiri. Seperti menyiapkan buku-buku pelajaran sesuai jadwal, alat tulis, dan memahami tentang tugas belajar di rumah yang harus mereka kerjakan. Ketika ada permasalahan pada proses belajar di rumah pun mereka juka akan lebih aktif mencari tahu dengan bertanya pada orang tua, kakak, teman, atau menghubungi guru untuk mendapatkan penjelasan tentang apa yang belum mereka pahami.

2) Pada variabel $X_{2}$ (dukungan keluarga) nilai $T_{\text {hitung }} \geq T_{\text {taabel }}(2,121 \geq 2,012)$ berarti $\mathrm{H}_{\mathrm{o}}$ ditolak dan $\mathrm{H}_{\mathrm{a}}$ diterima artinya variabel $\mathrm{X}_{2}$ (dukungan keluarga) memiliki pengaruh nyata dan signifikan secara parsial terhadap variabel Y (hasil belajar dirumah saat pandemi Covid-19). Godaan terbesar saat belajar di rumah adalah 
rasa malah dan acara televisi yang menarik atau permaian di gawai masingmasing. Disini peran orang tua menjadi sangat krusial untuk menemani putra putrinya belajar di rumah. Orang tua menjadi "the real teacher" saat pandemi. Tidak jarang ditemui orang tua yang semakin stress menghadapi tingkah anaknya saat belajar di rumah. Dukungan keluarga menjadi salah satu ujung tombak suksesnya proses belajar dari rumah siswa. Dukungan orang tua tidak hanya pada materi seperti tersedianya fasilitas internet saja, tetapi orang tua juga menjadi motivator siswa untuk tetap disiplin belajar di rumah.

Keseluruhan variabel bebas secara individu atau parsial masing-masing berpengaruh secara signifikan terhadap variabel terikat, sedangkan yang mempunyai pengaruh paling dominan dapat ditentukan dengan menghitung sumbangan proporsi dari masing-masing variabel bebas terhadap variabel terikat dengan cara sebagai berikut:

1) Proporsi sumbangan variabel $X_{1}$ (Self-Efficacy) terhadap variabel $Y$ (hasil belajar dirumah saat pandemi Covid-19)

$$
\mathrm{r}_{1} \mathrm{y} \times \beta_{1} \times 100 \%=0,812 \times 0,512 \times 100 \%=40,70 \%
$$

2) Proporsi sumbangan variabel $X_{2}$ (dukungan keluarga) terhadap variabel $Y$ (hasil belajar dirumah saat pandemi Covid-19)

$$
\mathrm{r}_{2} \mathrm{y} \times \beta_{2} \times 100 \%=0,308 \times 0,650 \times 100 \%=20,00 \%
$$

keterangan :

ry : koefisien korelasi antara variabel $\mathrm{X}$ dan $\mathrm{Y}$

$\beta$ : koefisien variabel pada standardized coefficients

Jumlah proporsi sumbangan variabel bebas secara keseluruhan berjumlah $60.7 \%$. hal ini sesuai dengan $\mathrm{R}$ Square dalam hasil perhitungan regresi linier berganda. Berdaasarkan hasil perhitungan tersebut variabel $\mathrm{X}_{1}$ (Self-Efficacy) merupakan variabel yang dominan mempengaruhi varibel terikat $\mathrm{Y}$ (hasil belajar dirumah saat pandemi Covid-19).

\section{d. Uji F}

Uji F digunakan untuk melihat signifikansi pengaruh dari variabel bebas $\mathrm{X}_{1}$ dan $\mathrm{X}_{2}$ secara simultan atau bersama-sama terhadap variabel terikat $\mathrm{Y}$ dengan level of significant $\alpha=5 \%$. Kriteria pengambilan keputusannya adalah:

1) Apabila $F_{\text {hitung }} \geq F_{\text {taabel }}$ berarti $H_{o}$ ditolak dan $H_{a}$ diterima, jadi semua varibel bebas (Self-Efficacy dan dukungan keluarga) secara simultan memiliki pengaruh yang nyata terhadap varibael terikat (hasil belajar dirumah selama pandemi Covid-19) 
2) Apabila $F_{\text {hitung }} \leq \mathrm{F}_{\text {taabel }}$ berarti $\mathrm{H}_{\mathrm{o}}$ diterima dan $\mathrm{H}_{\mathrm{a}}$ ditolak, jadi semua varibel bebas (Self-Efficacy dan dukungan keluarga) secara simultan tidak memiliki pengaruh yang nyata terhadap varibael terikat (hasil belajar dirumah selama pandemi Covid-19)

Hasil analisis Uji T disajikan dalam tabel berikut :

\begin{tabular}{|c|c|c|}
\hline $\mathbf{F}_{\text {hitung }}$ & $\mathbf{F}_{\text {tabel }}$ & Keterangan \\
\hline 16,018 & 3,195 & $\mathrm{~F}_{\text {hitung }} \geq \mathrm{F}_{\text {taabel }}$ berarti $\mathrm{H}_{\mathrm{o}}$ ditolak dan $\mathrm{H}_{\mathrm{a}}$ diterima \\
\hline
\end{tabular}

Berdasarkan hasil analisis uji $\mathrm{F}$ diatas, diketahui bahwa nilai $\mathrm{F}_{\text {hitung }} \geq \mathrm{F}_{\text {taabel }}$ dengan nilai $F_{\text {hitung }} \geq$ sebesar 16,018 dan nilai $F_{\text {taabel }}$ pada taraf signifikansi $5 \%$ dengan df1 = 5, serta df2 yang diperoleh dari perhitungan n-k-1 = 50-2-1=47, yaitu sebesar 3,195. Sehingga dapat disimpulkan bahwa $\mathrm{H}_{\mathrm{o}}$ ditolak dan $\mathrm{H}_{\mathrm{a}}$ diterima. Dengan demikian semua varibel bebas (Self-Efficacy dan dukungan keluarga) secara simultan memiliki pengaruh yang nyata terhadap variabel terikat (hasil belajar dirumah selama pandemi Covid-19).

\section{KESIMPULAN}

Self-Efficacy dan dukungan keluarga mejadi dua variabel pendukung suksesnya proses belajar dari rumah di masa pandemi saat ini. Keduanya menyumbangkan keberhasilan proses belajar di rumah sebesar 60,7\% dan sisanya dipengaruhi oleh faktor lain yang yang tidak di teliti. Faktor tersebut berasal dari dalam dan luar diri peserta didik dan dukungan keluarga, seperti kondisi geografis peserta didik, kesiapan guru pada proses pembelajaran dari rumah dan kesiapan guru dalam memadukan kurikulum luring pada implementasi pembelajaran daring seperti saat ini.

Self-Efficacy dan dukungan keluarga secara individu atau parsial masing-masing berpengaruh secara signifikan terhadap suksesnya proses belajar dari rumah di masa pandemi. Variabel yang mempunyai pengaruh paling dominan adalah variabel SelfEfficacy hal ini dapat ditentukan dengan menghitung sumbangan proporsi dari masingmasing variabel bebas terhadap variabel terikat. Proporsi sumbangan variabel $\mathrm{X}_{1}$ (SelfEfficacy) terhadap variabel Y (hasil belajar dirumah saat pandemi Covid-19). $\mathrm{r}_{1} \mathrm{y} \times \beta_{1} \mathrm{x}$ $100 \%=0,812 \times 0,512 \times 100 \%=40,70 \%$. Proporsi sumbangan variabel $\mathrm{X}_{2}$ (dukungan keluarga) terhadap variabel $\mathrm{Y}$ (hasil belajar dirumah saat pandemi Covid-19). $\mathrm{r}_{2} \mathrm{y} \times \beta_{2} \mathrm{x}$ $100 \%=0,308 \times 0,650 \times 100 \%=20,00 \%$. 


\section{DAFTAR RUJUKAN}

Alwisol. 2005. Psikologi Kepribadian. Malang: UMM Press

Baron, R.A. \& Byrne, D. 2003. Social Psychology. Boston: Pearson

Hendriana, H. (2014). Membangun kepercayaan diri siswa melalui pembelajaran matematika humanis. Jurnal Pengajaran MIPA, 19(1), 52-60.

Kim, U \& Park Y. 2006. Factor influencing academic achievement in relational cultures: the role of self relational, and collective efficacy. Jurnal Psikologi, 21(6).

Somawati. 2018. Peran Efikasi Diri (Self Efficacy) terhadap Kemampuan Pemecahan Masalah Matematika. Jurnal Konseling dan Pendidikan. Vol 6 Nomor 139 - 45

Taylor, S.E.Peplau, L.T. Sears, D.O. 2009. Psikologi Sosial, Edisi Kedua Belas. Jakarta: Kencana

Yuliyani, Handayani, \& Somawati -. 2017. Peran Efikasi Diri (Self Efficacy) Dan Kemampuan Berpikir Positif Terhadap Kemampuan Pemecahan Masalah Matematika. Jurnal Formatif, 130-143. 
Volume 4, Nomor 2, Agustus 2020 